\title{
Inclusion of grape pomace in the diet of pigs on pork quality and oxidative stability of omega-3 enriched fat
}

\author{
Teresinha Marisa Bertol ${ }^{1 *}$ Jorge Vitor Ludke ${ }^{1}$ Rogerio Manoel Lemes de Campos ${ }^{2}$ \\ Vicky Lilge Kawski ${ }^{1}$ Anildo Cunha Junior ${ }^{1}$ Elsio Antonio Pereira de Figueiredo ${ }^{1}$
} ${ }^{1}$ Embrapa Suínos e Aves, BR 153, KM 110, Vila Tamanduá, 89715-899, Concórdia, SC, Brasil. E-mail: teresinha.bertol@embrapa.br.
${ }^{*}$ Corresponding author.

${ }^{2}$ Fundação Universidade Federal do Vale do São Francisco (UNIVASF), Petrolina, PE, Brasil

ABSTRACT: The objective of this study was to assess the effects of including grape pomace in the diet of pigs on pork quality and oxidative stability of body fat enriched with omega-3 fatty acids. Four treatments were compared: T1) Control diet based on corn and soybean meal; T2) Diet with inclusion of $3 \%$ of a canola (50\%) and flaxseed (50\%) oil blend; T3) Diet with inclusion of 3\% of the oil blend and sequential levels of 3 and $5 \%$ of grape pomace; T4) Diet with inclusion of 3\% of the oil blend and sequential levels of 6 and $10 \%$ of grape pomace. Inclusion of grape pomace in the diet led to an increase $(P<0.10)$ of $a^{*}$ value and color saturation index of meat. The omega-3 and polyunsaturated fatty acids (PUFA) content of backfat were increased ( $P>0.10)$ with dietary inclusion of oils blend. Neither the inclusion of the oil blend, nor the grape pomace had any effect $(P>0.10)$ on the production of thiobarbituric acid reactive substances (TBARS) in the loin samples, despite the higher PUFA content in the fat of pigs fed the oil blend. Antioxidant effect of grape pomace was not possible to prove when measured by TBARS, but the increased redness of the pork from pigs fed with this ingredient suggested a possible antioxidant effect of grape pomace. Key words: grape pomace, natural antioxidants, omega-3, pork quality.

Inclusão do bagaço de uva na dieta de suínos sobre a qualidade da carne e a estabilidade oxidativa da gordura enriquecida com ômega-3

RESUMO: Este trabalho teve como objetivo avaliar a inclusão do bagaço de uva na dieta de suínos sobre a qualidade da carne e, a estabilidade oxidativa da gordura corporal enriquecida com ácidos graxos ômega-3. Foram comparados quatro tratamentos: T1 - Dieta controle baseada em milho e farelo de soja; T2 - Dieta com inclusão de 3\% de uma mistura de óleos de canola (50\%) e de semente de linho (50\%); T3 - Dieta com inclusão de 3\% da mistura de óleos e níveis sequenciais de 3 e 5\% de bagaço de uva e; T4 - Dieta com inclusão de 3\% da mistura de óleos e níveis sequenciais de 6 e 10\% de bagaço de uva. A inclusão do bagaço de uva na dieta resultou no aumento (P<0,10) do valor de $a^{*}$ e indice de saturação da cor da carne. O conteúdo de ômega-3 e ácidos graxos poli-insaturados (PUFA) do toucinho aumentaram $(P<0,10)$ em função da inclusão da mistura de óleos na dieta. A mistura de óleos e o bagaço de uva não afetaram a produção de substâncias reativas ao ácido tiobarbitúrico (TBARS) nas amostras de lombo, apesar do maior conteúdo de PUFA na gordura dos suínos que receberam a mistura de óleos na dieta. Não foi possível provar efeito antioxidante do bagaço de uva na carne através da determinação dos valores de TBARS. Porém, a cor vermelha mais intensa na carne dos suínos alimentados com este ingrediente sugere um possivel efeito antioxidante do bagaço de uva.

Palavras-chave: antioxidantes naturais, bagaço de uva, ômega-3, qualidade da carne.

\section{INTRODUCTION}

The enrichment of foods with omega-3 fatty acids has aroused consumer interest due to the potential beneficial effect of these lipids on human health. Inclusion of omega-3 fatty acid-rich ingredients in the diet of pigs leads to enriched body fat with these fatty acids (JUAREZ et al., 2010; BERTOL et al., 2013) because part of dietary fat is incorporated directly into animal tissues. However, the increased content of polyunsaturated fatty acids in the fat may negatively affect the quality of meat and processed products due to their reduced oxidative stability (DAZA et al., 2005; MUSELLA et al., 2009). To counteract this effect, one of the alternatives is the use of antioxidants, which may be added directly to the product or supplied through diet.

A wide variety of vegetables contains components with antioxidant properties and phenolic compounds, including phenolic acids, phenolic 
diterpenes, flavonoids and volatile oils (SHAN et al., 2005). Plant components and extracts containing antioxidant compounds have been intensively studied for use in the food industry. The presence of phenolic compounds with antioxidant activity in grape and its by-products and extracts has been confirmed in previous studies (ABE et al., 2007; ROTAVA et al., 2009). The main phenolic compounds reported in the residue composed by the grape skin and seeds are catechins, epicatechins, and gallic acid, in addition to several other phenolic acids (LAFKA et al., 2007). In the individual seeds, the most abundant phenolic compounds include catechins, epicatechins and also dimeric and trimeric procyanidins (SHI et al., 2003). Thus, the grape and its by-products are important sources of antioxidants with potential for use in the food processing industry and animal production. Antioxidant effect of grape seed extract when added directly to raw or cooked pork has been confirmed by CARPENTER et al. (2007). Also, the inclusion of concentrated grape pomace in the diet of chickens reduced lipid oxidation of raw or cooked meat (GOÑI et al., 2007; BRENES et al., 2008; SÁYAGOAYERDI et al., 2009), but the same effect was not observed when grape seed extract was given to pigs (O'GRADY et al., 2008). Therefore, the antioxidant effect of extracts or fractions of vegetables on animal products have not been well established when provided through the diet.

Furthermore, the inclusion of a potentially antioxidant ingredient such as grape pomace, concomitantly with a canola and flax seed oil blend in the diet could improve the oxidative stability of omega-3 fatty acid-enriched body fat. The objective of this study was to assess the effects of including grape pomace in the diet of pigs on pork quality and oxidative stability of body fat enriched with omega-3 fatty acids.

\section{MATERIALS AND METHODS}

Forty barrows of the genotype $\mathrm{MO} 25 \mathrm{C}$ $(80.0 \pm 1.7 \mathrm{~kg}$ body weight) were used for the study. The genotype MO25C was developed at the Embrapa Suínos e Aves, and its genetic composition is $25 \%$ Moura, 50\% Landrace, and 25\% Large White.

The experiment was conducted in a randomized complete block design with four treatments: T1) Control diet based on corn and soybean meal; T2) Diet with $3 \%$ of a canola $(50 \%)$ and flaxseed (50\%) oil blend; T3) Diet with 3\% of a canola (50\%) and flaxseed (50\%) oil blend and sequential levels of 3 and $5 \%$ of grape pomace; T4)
Diet with $3 \%$ of a canola (50\%) and flaxseed (50\%) oil blend and sequential levels of 6 and $10 \%$ of grape pomace. In T2, wheat bran was included in the diet to prevent an excessive increase of dietary energy due to the inclusion of the oil blend. In diets of T3 and T4, as the grape pomace was introduced in the diet, wheat bran was reduced by $50 \%$ and $100 \%$, respectively. The sequential levels of grape pomace were fed for 21 and 17 days, respectively. The pigs were individually identified and housed in groups of 10, according to the criterion of uniformity of initial body weight (block). One pen with 10 pigs was allotted in each treatment and the individual animal was the experimental unit. The pens were equipped with automatic feeders and nipple drinkers. The animals were weighed at the start of the trial, at day 21 and at the end of the experiment.

The diets were formulated according to the requirements of NRC (1998) for finishing pigs and were fed ad libitum. The grape pomace, containing skin and seeds was obtained from the extraction of juice for wine production and after sun dried, it contained $85.32 \%$ dry matter, $10.77 \%$ crude protein, $7.81 \%$ ether extract, $4.22 \%$ ash, $0.31 \% \mathrm{Ca}, 0.25 \%$ P. The content of total phenolic compounds was $70.90 \mathrm{mg}$ of gallic acid equivalent (GAE) $100^{-1} \mathrm{~g}$ sample. The pomace was milled in a hammer mill with a sieve opening of $3 \mathrm{~mm}$.

Animals were subjected to 12-hour fasting period prior to being transported to the abattoir, located $15 \mathrm{~km}$ from the farm, where they had five hours of lairage, with access to water but not food. Before bleeding the animals were stunned by electronarcosis. pH assessment was performed $45 \mathrm{~min}$ and $24 \mathrm{~h}$ after slaughter, in the longissimus thoracis muscle at the last rib (P2) and in the semimembranosus muscle, using a portable digital $\mathrm{pH}$ meter. Color scores (NPPC, 1999) and color by CIELAB color system (coordinates $\mathrm{L}^{*}, \mathrm{a}^{*}$ and $\mathrm{b}^{*}$, Minolta Camera Ltd., Japan) were evaluated 24 hours after slaughter.

Longissimus thoracis samples were collected for ether extract, thiobarbituric acid reactive substances (TBARS), cooking loss, and shear force analyses, and backfat samples for fatty acids analyses. These samples were frozen immediately after collection and transported to the laboratory, where they were stored at $-20^{\circ} \mathrm{C}$. Loin samples for ether extract analysis were thawed, milled in a multiprocessor, packed in disposable aluminium trays, frozen for 24 hours at $-25^{\circ} \mathrm{C}$ and lyophilized at $-40^{\circ} \mathrm{C}$ to $20^{\circ} \mathrm{C}$ (Liobrás LP810 Freeze dryer). After lyophilisation the samples were milled in a refrigerated mill (Foss Tecator 1095 - Sample Knifetec) and stored at $-25^{\circ} \mathrm{C}$. Samples for cooking 
loss were thawed under refrigeration at $5^{\circ} \mathrm{C}$ for 24 hours, boiled in a water bath at $75^{\circ} \mathrm{C}$ for 60 minutes and processed as described by HONIKEL (1998).

Ether extract was determined by means of an automated fat extractor (Ankon XT-15) according to AOCS (2004). TBARS analyses were performed on loin samples, immediately after thawing (day 0 ) and after three days of storage at $2^{\circ} \mathrm{C}$ to $6^{\circ} \mathrm{C}$ (day 3). Samples were thawed under refrigeration for 24 hours and ground in a food processor. Five grams of sample were used and the analysis conducted according to the procedure by WANG et al. (2002). Once the solution was mixed with trichloroacetic acid (TCA) and 7.5\% thiobarbituric acid (TBA) $0.08 \mathrm{M}$, the samples were subjected to a water bath for 80 minutes at $40^{\circ} \mathrm{C}$. Results were expressed as mg of malonaldehyde (MDA) $\mathrm{kg}^{-1}$ of sample. To determine the fatty acid profile, samples were prepared by saponification and esterification (HARTMAN \& LAGO, 1973) following extraction of total lipids according to FOLCH et al. (1956). Fatty acids were determined by gas chromatography (GC-FID Gas Chromatograph Varian CP-3800).

Analysis of variance was performed using the GLM procedure of SAS (SAS, 2011), considering the effects of treatment and block (initial weight). The treatment means, when this effect was significant, were compared using the protected t test $(\mathrm{P}<0.10)$. Treatments were also compared using orthogonal contrasts: Treatment 1 vs treatments 2, 3 and 4; treatment 2 vs treatments 3 and 4; treatment 3 vs. treatment 4 .

\section{RESULTS AND DISCUSSION}

The $\mathrm{pH}$ measured 24 hours after slaughter was higher $(\mathrm{P}<0.06)$ in animals fed with diet containing the oil blend but without grape pomace (T2), compared to all the other treatments (Table 1). Loin samples of pigs fed with the control diet had the highest ether extract content, $\mathrm{a}^{*}$ and $\mathrm{b}^{*}$ values, and colour saturation index $(\mathrm{P}<0.05$ to $\mathrm{P}<0.10$, respectively). However, the $\mathrm{b}^{*}$ value and colour saturation index increased in pigs fed with diets with grape pomace at any level $(\mathrm{P}<0.10$ and $\mathrm{P}<0.05$, respectively (contrast $\mathrm{T} 2$ vs. $\mathrm{T} 3$ and $\mathrm{T} 4)$, whereas the $\mathrm{a}^{*}$ value increased $(\mathrm{P}<0.10)$ only in those receiving the highest grape pomace levels $\left(6 / 10 \%\right.$, contrast T3 vs. T4). The $\mathrm{a}^{*}$ value is influenced both by the myoglobin concentration in the muscle and the reduction/oxidation state of the myoglobin (MANCINI \& HUNT, 2005); whereas, the colour saturation index is partially dependent on these factors, as it results from a calculation using $\mathrm{a}^{*}$ and $b^{*}$ values. One possible explanation for the lower $a^{*}$ values of meat from pigs which were fed with oil blend diets could be the lower oxidative stability of fat due to the elevated PUFA, which might lead to myoglobin oxidation. The $\mathrm{a}^{*}$ value increase in the meat of pigs fed with diet containing the highest levels of grape pomace could be due to an increased content of tocopherols in the tissues, which would prevent myoglobin oxidation.

Supplementing the diets with the blend of oils resulted in reduced levels $(\mathrm{P}<0.05)$ of ether extract in the longissimus thoracis and $\mathrm{C} 16: 0$ $\left(26.11 \pm 0.59^{\mathrm{a}}, 23.67 \pm 0.51^{\mathrm{b}}, 24.41 \pm 0.51^{\mathrm{b}}, 24.08 \pm 0.51^{\mathrm{b}}\right.$ $\%$ for $\mathrm{T} 1, \mathrm{~T} 2, \mathrm{~T} 3$, and $\mathrm{T} 4$, respectively) and the sum of saturated fatty acids (SFA, $\mathrm{P}<0.10$ ) in the backfat, but without altering $(\mathrm{P}>0.10)$ the proportion of other individual SFA or the proportion of monounsaturated fatty acids (MUFA; Table 2). The proportion of fatty acids C18:2, C18:3, C20:4, total PUFA and omega-6 were greater $(\mathrm{P}<0.10$ to 0.01$)$ in the backfat of pigs fed the diets containing the oil blend, consequently, the SFA/PUFA and omega-6/omega-3 ratios were reduced $(\mathrm{P}<0.01)$ and the iodine value was increased $(\mathrm{P}<0.01)$. The change in the fatty acid profile of the backfat was expected because of the addition of oils blend in the diet, due to the $\mathrm{C} 18: 3$ content in canola and flax seed oils, as reported in previous studies (JUÁREZ et al., 2010; BERTOL et al., 2013).

The inclusion of grape pomace in the diet did not affect $(\mathrm{P}>0.10)$ the backfat fatty acid profile, apart from the $\mathrm{C} 18: 3$ content, which was slightly reduced compared to the oil blend-supplemented diet without grape pomace $(\mathrm{P}<0.10$, contrast $\mathrm{T} 2$ vs. T3 and T4). The C18:2 fatty acid content in the backfat suffered no further changes by the addition of grape pomace in the diet, other than that caused by oils blend. This is because the $\mathrm{C} 18: 2$ content in the ether extract of this ingredient $(52 \%)$ does not greatly differ from the oil contained in corn and soybean meal. The omega-6/omega- 3 ratio of the backfat was reduced to values ranging from 4.15 to 4.71 due to the dietary addition of oil blend, which is in line with World Health Organization recommendations for human diet. The iodine value, despite being raised in the backfat of pigs fed with the oil blend-supplemented diets, remained within the limit considered acceptable, which is between 70 to $75 \mathrm{~g} .100 \mathrm{~g}^{-1}$ of fat (BENZ et al., 2010).

Neither the inclusion of the oil blend, nor the grape pomace had any effect $(\mathrm{P}>0.10)$ on the production of TBARS in the loin samples, despite the higher PUFA content in the fat of pigs fed with the oil blend. The TBARS content determined in 
Table 1 - Effect of inclusion of grape pomace and a blend of oils in the diet of pigs on $\mathrm{pH}, \mathrm{L}^{*}, \mathrm{a}^{*}$ and $\mathrm{b}^{*}$ values, color saturation index (CSI), colour score, ether extract (EE), coking loss, and thiobarbituric reactive substances (TBARS) of meat (mean \pm standard error).

\begin{tabular}{|c|c|c|c|c|c|c|c|c|}
\hline Treatment & 1 & 2 & 3 & 4 & \multirow{3}{*}{$\begin{array}{l}\operatorname{Pr}>F \\
\text { Treat }\end{array}$} & \multicolumn{3}{|c|}{------------ $\mathrm{Pr}>\mathrm{F}$ Contrasts--------- } \\
\hline Oil blend, \% & 0 & 3 & 3 & 3 & & & & \\
\hline GP, $\%$ & 0 & 0 & $3-5$ & $6-10$ & & 1 vs. $2,3,4$ & 2 vs. 3,4 & 3 vs. 4 \\
\hline $\mathrm{pH} 45 \min$ & $6.02 \pm 0.04$ & $6.04 \pm 0.06$ & $6.05 \pm 0.04$ & $6.01 \pm 0.04$ & $\mathrm{~ns}$ & ns & ns & ns \\
\hline $\mathrm{pH} 24 \mathrm{~h}$ & $5.59 \pm 0.03^{b}$ & $5.71 \pm 0.04^{\mathrm{a}}$ & $5.61 \pm 0.01^{\mathrm{b}}$ & $5.62 \pm 0.04^{\mathrm{b}}$ & * & ns & $* *$ & ns \\
\hline $\mathrm{L}^{*}$ & $47.67 \pm 0.75$ & $45.91 \pm 0.65$ & $47.71 \pm 0.82$ & $45.99 \pm 0.86$ & ns & ns & ns & ns \\
\hline$a^{*}$ & $4.70 \pm 0.35^{\mathrm{a}}$ & $3.85 \pm 0.15^{\mathrm{b}}$ & $3.87 \pm 0.20^{\mathrm{b}}$ & $4.45 \pm 0.26^{\mathrm{ab}}$ & $* *$ & ** & ns & * \\
\hline$b^{*}$ & $3.57 \pm 0.42$ & $2.19 \pm 0.27$ & $3.22 \pm 0.30$ & $3.04 \pm 0.45$ & ns & $*$ & * & ns \\
\hline CSI & $5.97 \pm 0.46^{\mathrm{a}}$ & $4.03 \pm 0.48^{\mathrm{b}}$ & $5.09 \pm 0.26^{\mathrm{ab}}$ & $5.48 \pm 0.40^{\mathrm{a}}$ & $* * *$ & $* *$ & $* * *$ & ns \\
\hline Colour score & $3.40 \pm 0.16$ & $3.56 \pm 0.18$ & $3.30 \pm 0.15$ & $3.60 \pm 0.16$ & ns & ns & ns & ns \\
\hline $\mathrm{EE}, \%$ & $2.36 \pm 0.226$ & $1.84 \pm 0.065$ & $1.92 \pm 0.217$ & $2.00 \pm 0.217$ & ns & $* *$ & $\mathrm{~ns}$ & ns \\
\hline $\mathrm{CL}, \%$ & $30.90 \pm 0.72$ & $27.89 \pm 0.87$ & $29.41 \pm 1.03$ & $29.29 \pm 0.97$ & ns & ns & ns & ns \\
\hline $\begin{array}{l}\text { TBARS d } 0, \mathrm{mg} \\
\mathrm{MDAkg}^{-1}\end{array}$ & $0.569 \pm 0.075$ & $0.547 \pm 0.080$ & $0.631 \pm 0.075$ & $0.584 \pm 0.086$ & ns & ns & ns & ns \\
\hline $\begin{array}{l}\text { TBARS d 3, mg } \\
\text { MDAkg }^{-1}\end{array}$ & $0.683 \pm 0.136$ & $0.617 \pm 0.146$ & $0.691 \pm 0.136$ & $0.591 \pm 0.158$ & ns & ns & ns & ns \\
\hline
\end{tabular}

Treat $=$ treatment; $\mathrm{GP}=$ grape pomace

${ }^{\text {abc }}$ Means in rows with different superscripts are significantly different by protected $\mathrm{t}$ test $(\mathrm{P}<0.10)$. ns: Not significant $(\mathrm{P}>0.10),{ }^{*} \mathrm{P}<0.10,{ }^{* *} \mathrm{P}<0.05,{ }^{* * *} \mathrm{P}<0.01$.

all treatments in this study lies within the range for detection of rancid odour in pork, which is between 0.5 and $1 \mathrm{mg} \mathrm{MDA.} \mathrm{kg}^{-1}$ of tissue (TARLADGIS et al., 1960). These results indicated that the dietary grape pomace had no antioxidant effect on the lipids of the meat and confirm the reports of O'GRADY et al. (2008), who reported no protective effect of grape seed extract on meat-associated lipids, when provided in the diet of pigs. Conversely, these results differ from several previous studies, where the addition of various plant extracts, essential oils or parts containing antioxidant compounds to the diets of pigs (MASON et al., 2005; LAHUCKY et al., 2010) or poultry (RACANICCI et al., 2011; ÁVILA-RAMOS et al., 2013; LOETSCHER et al., 2013) demonstrated positive results regarding to oxidative stability of the meat or meat products; although, not all assessed vegetables had the same antioxidant power, and one of them even demonstrated pro-oxidant effect (LOETSCHER et al., 2013). Oral supplementation of flavonoids such as catechin, epicatechin and quercetins in the diet leads to increased in vivo concentrations of vitamin $\mathrm{E}$ in the tissues (FRANK, 2005). Therefore, the antioxidant effect of phenolic compounds on animal tissues and by-product would seem to be related to this fact. However, this effect, as well as the deposition and storage dynamics of vitamin $\mathrm{E}$ in the tissues may vary from one species to another. For example, the concentration of tocopherols in poultry tissues in response to dietary supplementation is greater in the liver followed by muscle and fat (FLACHOWSKY et al., 2002) whereas in pigs, build-up and increased concentration occur in larger quantities in fat, followed by the liver, and then the muscle. This could explain the different antioxidant effect of grape pomace and other vegetable among chickens and pigs, when evaluated in meat samples. It is possible that longer periods of inclusion of grape pomace in the diet would increase vitamin $\mathrm{E}$ concentration in the muscle and thereby achieve an antioxidant effect on meat.

Another possible explanation for the lack of antioxidant effect of the grape pomace in this study is that the procyanidin oligomers may not have been properly digested and absorbed in the digestive tract as suggested by O'GRADY et al. (2008). Although no antioxidant effect of grape pomace as measured by the production of TBARS has been proven in this study, it is important to emphasize the increasing value of $\mathrm{a}^{*}$ in the meat of pigs fed with grape pomace, which could be an indicator of reduced myoglobin oxidation. 
Table 2 - Effect of inclusion of grape pomace and oils blend in the diet of pigs on fatty acids composition (percent of ether extract), n-6/n-3 ratio, and iodine value (IV) of backfat (mean \pm standard error).

\begin{tabular}{|c|c|c|c|c|c|c|c|c|}
\hline Treatment & 1 & 2 & 3 & 4 & \multirow{3}{*}{$\begin{array}{l}\operatorname{Pr}>F \\
\text { Treat }\end{array}$} & \multicolumn{3}{|c|}{------------Pr>F Contrasts--------- } \\
\hline Oil blend, $\%$ & 0 & 3 & 3 & 3 & & & & \\
\hline GP, \% & 0 & 0 & $3-5$ & $6-10$ & & 1 vs. $2,3,4$ & 2 vs. 3,4 & 3 vs. 4 \\
\hline SFA & $40.81 \pm 0.97^{\mathrm{a}}$ & $37.00 \pm 0.84^{\mathrm{b}}$ & $38.36 \pm 0.84^{\mathrm{b}}$ & $37.55 \pm 0.84^{b}$ & * & $* * *$ & ns & ns \\
\hline C16:1 & $1.905 \pm 0.150$ & $1.810 \pm 0.130$ & $1.589 \pm 0.130$ & $1.748 \pm 0.130$ & Ns & ns & ns & ns \\
\hline C18:1 & $42.15 \pm 0.67$ & $41.29 \pm 0.58$ & $41.22 \pm 0.58$ & $41.44 \pm 0.58$ & Ns & ns & ns & ns \\
\hline $\mathrm{C} 18: 2$ & $11.01 \pm 0.51^{\mathrm{b}}$ & $13.02 \pm 0.44^{\mathrm{a}}$ & $12.68 \pm 0.44^{\mathrm{a}}$ & $12.74 \pm 0.44^{\mathrm{a}}$ & * & *** & ns & ns \\
\hline C18:3 & $0.568 \pm 0.188^{c}$ & $3.401 \pm 0.163^{\mathrm{a}}$ & $2.930 \pm 0.163^{b}$ & $3.028 \pm 0.163^{\mathrm{ab}}$ & *** & $* * *$ & * & ns \\
\hline $\mathrm{C} 20: 1$ & $0.937 \pm 0.087$ & $0.771 \pm 0.075$ & $0.861 \pm 0.075$ & $0.814 \pm 0.075$ & ns & ns & ns & ns \\
\hline $\mathrm{C} 20: 2$ & $0.488 \pm 0.039$ & $0.502 \pm 0.034$ & $0.507 \pm 0.034$ & $0.483 \pm 0.034$ & ns & ns & ns & ns \\
\hline $\mathrm{C} 20: 4$ & $0.265 \pm 0.027^{b}$ & $0.540 \pm 0.024^{\mathrm{a}}$ & $0.496 \pm 0.024^{\mathrm{a}}$ & $0.489 \pm 0.024^{\mathrm{a}}$ & $* * *$ & $* * *$ & ns & ns \\
\hline MUFA & $44.99 \pm 0.70$ & $43.87 \pm 0.61$ & $43.67 \pm 0.61$ & $44.00 \pm 0.61$ & ns & ns & ns & ns \\
\hline PUFA & $12.34 \pm 0.66^{\mathrm{b}}$ & $17.46 \pm 0.61^{\mathrm{a}}$ & $16.61 \pm 0.61^{\mathrm{a}}$ & $16.73 \pm 0.61^{\mathrm{a}}$ & $* * *$ & $* * *$ & ns & ns \\
\hline$n-6$ & $11.77 \pm 0.51^{\mathrm{b}}$ & $14.06 \pm 0.44^{\mathrm{a}}$ & $13.68 \pm 0.44^{\mathrm{a}}$ & $13.71 \pm 0.44^{\mathrm{a}}$ & $* *$ & $* * *$ & ns & ns \\
\hline SFA/PUFA & $3.33 \pm 0.14^{\mathrm{a}}$ & $2.13 \pm 0.12^{b}$ & $2.33 \pm 0.12^{\mathrm{b}}$ & $2.24 \pm 0.12^{\mathrm{b}}$ & $* * *$ & $* * *$ & ns & ns \\
\hline$n-6 / n-3$ & $20.71 \pm 0.28^{\mathrm{a}}$ & $4.15 \pm 0.24^{b}$ & $4.71 \pm 0.24^{\mathrm{b}}$ & $4.55 \pm 0.24^{b}$ & $* * *$ & $* * *$ & ns & ns \\
\hline $\mathrm{IV}^{\mathrm{d}}$ & $59.36 \pm 1.29^{\mathrm{b}}$ & $69.28 \pm 1.12^{\mathrm{a}}$ & $67.26 \pm 1.12^{\mathrm{a}}$ & $67.92 \pm 1.12^{\mathrm{a}}$ & $* * *$ & *** & ns & ns \\
\hline
\end{tabular}

$\mathrm{GP}=$ grape pomace; $\mathrm{SFA}=$ saturated fatty acids; MUFA= monounsaturated fatty acids; PUFA= polyunsaturated fatty acid; TREAT= treatment.

${ }^{a b c}$ Means in rows with different superscripts are significantly different by protected $t$ test $(\mathrm{P}<0.10)$.

ns: Not significant $(\mathrm{P}>0.10),{ }^{*} \mathrm{P}<0.10,{ }^{* *} \mathrm{P}<0.05,{ }^{* * *} \mathrm{P}<0.01$.

${ }^{\mathrm{d}}$ Calculated values (Iodine value $=(\% \mathrm{C} 16: 1 \times 0.95)+(\% \mathrm{C} 18: 1 \times 0.86)+(\% \mathrm{C} 18: 2 \times 1.732)+(\% \mathrm{C} 18: 3 \times 2.616)+(\% \mathrm{C} 20: 1 \times 0.785)+(\%$ C22:1x0.723)).

\section{CONCLUSION}

Dietary supplementation with grape pomace improved meat color by increasing redness and colour saturation. Despite the increase in the content of PUFA in body fat of pigs fed with the oil blend it was not possible to prove protective effect of including grape pomace in the diet on lipid oxidation as measured by TBARS production, but the increased redness of the pork suggested a possible antioxidant effect of grape pomace.

\section{BIOTHICS AND COMMITTEE APPROVAL}

This study was approved by the Ethics Committee on Animal Use in Research (CEUA/CNPSA), protocol n. 004/2009, in accordance to the ethical principles established by the Brazilian College of Animal Experimentation.

\section{REFERENCES}

AOCS (AMERICAN OIL CHEMISTS SOCIETY). Official procedure. Approved Procedure Am 5-04, Rapid determination of oil/fat utilizing high temperature solvent extraction. Urbana, IL: American Oil Chemists Society, 2004.
ÁVILA-RAMOS, F. et al. Dietary supplemented and meat-added antioxidants effect on the lipid oxidative stability of refrigerated and frozen cooked chicken meat. Poultry Science, v.92, n.1, p.243-249, 2013. Available from: <http://ps.oxfordjournals. org/content/92/1/243.full.pdf+html $>$. Accessed: Nov. 19, 2013. doi: $10.3382 /$ ps.2012-02409.

BENZ, J.M. et al. Effects of dried distillers grains with solubles on carcass fat quality of finishing pigs. Journal of Animal Science, v.88, n.11, p.3666-3682, 2010. Available from: $<$ https://www. animalsciencepublications.org/publications/jas/pdfs/88/11/3666>. Accessed: Mar. 27, 2014. doi:10.2527/jas.2010-2937.

BERTOL, T.M. et al. Effects of genotype and dietary oil supplementation on performance, carcass traits, pork quality and fatty acid composition of backfat and intramuscular fat. Meat Science, v.93, n.3, p.507-516, 2013. Available from: <http:// www.sciencedirect.com/science/article/pii/S0309174012003737>. Accessed: Mar. 30, 2013. doi:10.1016/j.meatsci.2012.11.012.

BRENES, A. et al. Effect of grape pomace concentrate and vitamin E digestibility of polyphenols antioxidant activity in chickens. Poultry Science, v.87, n.2, p.307-316, 2008. Available from: $<$ http://ps.oxfordjournals.org/content/87/2/307.full.pdf + html $>$. Accessed: Nov. 22, 2013. doi:10.3382/ps.2007-00297.

CARPENTER, R. et al. Evaluation of the antioxidant potential of grape seed and bearberry extracts in raw and cooked pork. Meat Science, v.76, n.4, p.604-610, 2007. Available from: $<$ http://www. sciencedirect.com/science/article/pii/S030917400700037X>. Accessed: Feb. 02, 2013. doi:10.1016/j.meatsci.2007.01.021. 
DAZA, A. et al. Effects of feeding in free-range conditions or in confinement with diferent dietary MUFA/PUFA ratios and $\alpha$-tocopheryl acetate, on antioxidants accumulation and oxidative stability in Iberian pigs. Meat Science, v.69, n.1, p.151-163, 2005. Available from: $<$ http://www.sciencedirect.com/science/article/pii/ S0309174004001731>. Accessed: Apr. 09, 2014. doi:10.1016/j. meatsci.2004.06.017.

FLACHOWSKY, G. et al. Eggs and poultry meat as tocopherol sources in dependence on tocopherol supplementation of poultry diets. Food Research International, v.35, n. 2-3, p.239-243, 2002. Available from: <http://www.sciencedirect.com/science/article/ pii/S0963996901001910>. Accessed: Mar. 11, 2015. doi:10.1016/ S0963-9969(01)00191-0.

FOLCH, J. et al. A simple method for the isolation and purification of total lipids from animal tissues. Journal of Biological Chemistry, v.226, n.1, p.497-509, 1957. Available from: <http:// www.jbc.org/content/226/1/497.full.pdf +html>. Accessed: June01, 2015.

FRANK, J. Beyond vitamin E supplementation: An alternative strategy to improve vitamin $E$ status. Journal of Plant Physiology, v.162, n.7, p.834-843, 2005. Available from: <http:// www.sciencedirect.com/science/article/pii/S0176161705001446>. Accessed: Jul. 07, 2014. doi:10.1016/j.jplph.2005.04.017.

GOÑI, I. et al. Effect of dietary grape pomace and vitamin E on growth performance, nutrient digestibility, and susceptibility to meat lipid oxidation in chickens. Poultry Science, v.86, n.3, p.508-516, 2007. Available from: <http:// ps.oxfordjournals.org/content/86/3/508.full.pdf + html $>$. Accessed: Nov. 22, 2013

HARTMAN, L.; LAGO, R.C.A. Rapid preparation of fatty acid methyl esters from lipids. Laboratory Practices, v.22, p.475-481, 1973.

HONIKEL, K.O. Reference methods for the assessment of physical characteristics of meat. Meat Science, v.49, n.4, p.447-457, 1998. Available from: <http://www.sciencedirect.com/science/article/ pii/S0309174098000345>. Accessed: Mar. 25, 2011. doi:10.1016/ s0309-1740(98)00034-5.

JUÁREZ, M. et al. Feeding co-extruded flaxseed to pigs: Effects of duration and feeding level on growth performance and backfat fatty acid composition of grower-finisher pigs. Meat Science, v.84, n.3, p.578-584, 2010. Available from: <http://www.sciencedirect. com/science/article/pii/S0309174009003350>. Accessed: Nov. 19, 2013.doi:10.1016/j.meatsci.2009.10.015.

LAFKA, T.I.et al. On the extraction and antioxidant activity of phenolic compounds from winery wastes. Food Chemistry, v.104, p.1206-1214, 2007.Available from: <http://www.sciencedirect. com/science/article/pii/S0308814607001264>. Accessed: Nov. 20, 2013. doi:10.1016/j.foodchem.2007.01.068.

LAHUCKY, R.et al. Assessment of the antioxidant potential of selected plant extracts - In vitro and in vivo experiments on pork. Meat Science, v.85, n.4, p.779-784, 2010. Available from: <http:// www.sciencedirect.com/science/article/pii/S0309174010001282>. Accessed: Oct. 07, 2011. doi:10.1016/j.meatsci.2010.04.004.

LOETSCHER, Y. et al. Oxidative stability of the meat of broilers supplemented with rosemary leaves, rosehip fruits, chokeberry pomace, and entire nettle, and effects on performance and meat quality. Poultry Science, v.92, p.2938-2948, 2013. Available from: $<$ http://ps.oxfordjournals.org/content/92/11/2938.full.pdf + html $>$. Accessed: Nov. 19, 2013. doi:10.3382/ps.2013-03258.

MANCINI, R.A.; HUNT, M.C. Current research in meat color. Meat Science, v.71, n.1, p.100-121, 2005. Available from: $<$ http://www. sciencedirect.com/science/article/pii/S030917400500094X>. Accessed: May 29, 2015. doi:10.1016/j.meatsci.2005.03.003.

MASON, L.M. et al. Effects of restricted feeding and antioxidant supplementation on pig performance and quality characteristics of Longissimus dorsi muscle from Landrace and Duroc pigs. Meat Science, v.70, n.2, p.307-317, 2005. Avalialble from: <http://www.sciencedirect.com/science/ article/pii/S0309174005000598>. Accessed: Aug. 11, 2012. doi:10.1016/j.meatsci.2005.01.017.

MUSELLA, M. et al. Omega-3 polyunsaturated fatty acid from extruded linseed influences the fatty acid composition and sensory characteristics of dry-cured ham from heavy pigs. Journal of Animal Science, v.87, n.11, p.3578-3588, 2009. Available from: $<$ https://www.animalsciencepublications.org/publications/ jas/pdfs/87/11/3578>. Accessed: Mar. 03, 2014. doi: 10.2527/ jas.2008-1355.

NPPC. Pork quality standards. Des Moines, IA: National Pork Producers Council, 1999. 1p.

NRC. Nutrient requirements of swine. 10.rev.ed. Washington, DC: Natl Acad, 1998. 189p.

O'GRADY, M.N. et al. Addition of grape seed extract and bearberry to porcine diets: Influence on quality attributes of raw and cooked pork. Meat Science, v.78, n.4, p.438-446, 2008. Available from: $<$ http://www.sciencedirect.com/science/article/pii/ S0309174007002446>. Accessed: Feb. 02, 2013. doi:10.1016/j. meatsci.2007.07.011.

RACANICCI, A.M.C. et al. Mate (Ilex paraguariensis) as dietary additive for broilers: performance and oxidative stability of meat. European Food Research Technology, v.232, p.655-661, 2011. Available from: <http://link.springer.com/article/10.1007/ s00217-011-1432-x>. Accessed: Dec. 12, 2011. doi: 10.1007/ s00217-011-1432-x.

ROTAVA, R. et al. Antibacterial, antioxidant and tanning activity of grape by-product. Ciencia Rural, v.39, n.3, p.941-944, 2009. Available from: $<$ http://www.scielo.br/scielo.php?Script=sci arttext\&pid $=$ S0103-84782009000300051\&lng $=$ pt\&nrm $=$ is o\&tlng=pt $>$. Accessed: Mar. 11, 2015. doi:10.1590/S010384782009000300051 .

SÁYAGO-AYERDI, S.G.et al. Antioxidative effect of dietary grape pomace concentrate on lipid oxidation of chilled and long-term frozen stored chiken patties. Meat Science, v.83, n.3, p.528-533, 2009. Available from: <http://www.sciencedirect.com/ science/article/pii/S030917400900196X>. Acessed: Feb. 02, 2013. doi:10.1016/j.meatsci.2009.06.038.

SAS Institute Inc. SAS/STAT user's guide: statistics. Cary, 2001. Version 8.

SHAN, B. et al. The in vitro antibacterial activity of dietary spice and medicinal herb extracts. International Journal of Food Microbiology, v.117, n.1, p.112-119, 2007. Available from: <http:// ac.els-cdn.com/S0168160507001778/1-s2.0-S0168160507001778- 
main.pdf>. Accessed: May 29, 2015. doi: 10.1016/j. ijfoodmicro.2007.03.003.

SHI, J. et al. Polyphenolics in grape seeds - Biochemistry and functionality. Journal of Medicinal Food, v.6, n.4, p.291299, 2003. Available from: <http://online.liebertpub.com/doi/ pdfplus/10.1089/109662003772519831>. Accessed: Nov. 22, 2013. doi: $10.1089 / 109662003772519831$.

TARLADGIS, B.G. et al. A distillation method for quantitative determination of malonaldehyde in rancid foods. Journal of the American Oil Chemists' Society, v.37, n.1, p.44-48, 1960. Available from: <http://link.springer.com/article/10.1007/ BF02630824>. Accessed: Nov. 27, 2013.

WANG, B. et al. Modified extraction method for determining 2-thiobarbituric acid values in meat with increased specificity and simplicity. Journal of Food Science, v.67, n.8, p.2833-2836, 2002. Available from: <http:// onlinelibrary.wiley.com/doi/10.1111/j.1365-2621.2002. tb08824.x/epdf $>$. Accessed: Mar. 11, 2015. doi: 10.1111/ j.1365-2621.2002.tb08824.x. 